https://doi.org/10.3126/pragya.v8i01.42345

\title{
The Influence of Packaging Design on Buying Behavior of Women in Lalitpur Metropolitan City for Cosmetic Products
}

\author{
- Soma Raj Khanal* \\ - Bishnu Prasad Pokhrel ${ }^{*}$
}

\begin{abstract}
Perception of the consumer towards the selection of cosmetic products is influenced by the packaging of the product. However, an empirical research on understanding how visual effects of packaging influence women' consequent product and brand evaluation is scant. This study examines the buying behavior toward the effect of visual packaging on perceived product's quality, product's value, and brand preference. A self-administered questionnaire developed from the literature was used to conduct the response survey in January 2020 on Psatan area where response of 315 women-participants were received during the survey. The empirical results show that attitudes towards visual packaging have the major influence on perception towards product quality and brand preference on buying behavior. Moreover, classic and simple style packaging is popular in Nepalese context. Furthermore, consumers in Lalitpur City were not different than consumers from other cities.
\end{abstract}

Key Words: brand preference, buying behavior, cosmetic products, perceived quality, perceived value, visual product's packaging design.

\section{Introduction}

Understanding the buying behavior of a consumer is at the heart of commercial success in today's competitive markets (Estireet al.,2010). Packaging was one of the critical factors that affected the purchasing behavior (Silayoi \& Speece, 2007). Other factors include searching, income, quality and characteristics of the product. Therefore, consumer studies were more focused upon these types of behaviors (Johns \& Pine, 2002; Grunert, 2005).

The communication exchange between the package elements and the consumer determined the acceptability of products (Venteret al., 2010). Package elements involved visual and informational attributes (Silayoi \& Speece, 2007). Visual attributes (color, shape, image, design, logo and illustration) were associated with affective side of decision making, while

\footnotetext{
* Mr. Khanal is an assistant Professor of Management, Patan Multiple Campus, TU, Nepal

* Mr. Pokhrel is a faculty member of Nepal Open University
} 
informational elements (labels, instructions, cultural context and segmentation) were related to the cognitive side of determination (Estireet al., 2010; Venteret al., 2010).

The effective communication of product advantages through the packaging design determines consumers' first and sometimes lasting impression of the product (Ghani \& Kamal, 2010), as consumers pay more attention to the way a product is presented than to the product itself (Silayoi \& Speece, 2007). Since consumers predominantly prefer products that visually attract their attention (Grunert, 2005), food packaging must be attractive or eyecatching with regard to color, typography, graphical shapes and images, text, design, logo and illustrations.

Behzad (2014) says packaging and the position of various mediating factors, such as graphics, design and color, contribute to the success of branding and marketing and color is ubiquitous and a source of mediation. Individuals will be able to decide between 62-90 percent of the test is based on colors in 90 seconds from their initial contact with either person or product.

Most impulse buying occurs because of product display; and attractive packaging plays an important role in product display (Ghani and Kamal, 2010). Point-of-purchase decisions heighten the potential for product packaging to communicate information to consumers and influence product choice (Clement, 2007). Previous studies have indicated that packaging is a marketing communication vehicle (Silayoi and Speece, 2007; Hellstrom and Nilsson, 2011) used to capture consumer attention (Thalhammer, 2007), which affects the product selection process (Hall et al., 2004). Therefore, product packaging provides an opportunity to communicate with and influence the consumerat the point of purchase (Atkin et al., 2006; Wigley and Chiang, 2009).

De Bono et al. (2003) argued that attractive product packaging indicates a favorable product. Previous studies have suggested that packaging attributes can be classified as verbal and visual cues (Kauppinen-Raisanen et al., 2012), and that the two types of packaging cues induce different types of cognitive processing. Whereas processing verbal cues into mental images require intentional effort, processing visual cues has been found to be unconscious and unintentional (Mueller et al., 2010). For high-involvement goods, the packaging design may focus on verbal cues that provide a means of comparing products in a self-service store. In contrast, packaging for low-involvement goods may focus on visual cues that provide the amount of physical and psychological benefits (Sehrawet and Kundu, 2007). Researchers generally believe that visual packaging is key to gaining consumer instore attention (Silayoi and Speece, 2007; Venter et al., 2011; Honea and Horsky, 2012). Furthermore, when consumers do not have prior knowledge of a product's qualities, visual 
packaging cues may attract consumer's attention and set expectations for the product content of the verbal elements (Silayoi and Speece, 2007).

Moreover, product quality was an important attribute for consumers when discussing consumer retailing (Noad and Rogers, 2008). Consumer-perceived product quality is the consumer judgment of the overall excellence or superiority of a product (Anselmsson et al., 2007). In the study, perceived cosmetic product quality referred to the customer assessment of the guarantee or superiority of the cosmetic product under consideration. Previous research has suggested that consumer attitudes are formed by learning and influenced by personal experience and marketing stimuli (Wang and Heitmeyer, 2006). Additionally, product packages consist of an array of cues (Kabir Chowdhury and Andaleeb, 2007) that serve as surrogate indicators of product quality (Ampuero and Vila, 2006; Insch and Florek,2009). In this study, "attitudes towards visual packaging design" refers to the consumers' feeling of favorability towards the packaging attributes or features, including the specificchoice of color, type, face, graphics, and size.

Sehrawet and Kundu (2007), consumers are likely to form product benefit perceptions when exposed to or evaluating visual packaging cues. Because product quality information is difficult to pre-obtain (Linn et al., 2012), visual attributes are perceived as an indication of product quality (Venter et al., 2011; Honea and Horsky, 2012). Based on this reasoning, this study aims to identify the influence of packaging on female consumer buying behavior decision of cosmetic products.

\section{Research Methodology}

\section{Research environment, sample, and data collection}

A survey research has been conducted in Lalitpur Metropolitan City in January 2020. In total, 315 women of different age group as well as income level from various business classes were participated in this study. The survey questionnaires had been distributed in 3 days from different core areas of the city. All the respondents gave the responses that have shopping experience of cosmetic products. The study participants were asked to report their attitudes towards the product packaging visual features and provide a product/brand evaluation. The research questionnaires were designed on 5 point Likert-scale with different demographic variable. 


\section{Analysis and Results}

\section{Characteristics of the respondents}

The respondents are segmented by different age groups, different nationalities, and different income per month. Here, the customer is analyzed in different age groups and different income level.

\section{Table 1}

Frequency Table of Age Group

\begin{tabular}{|l|c|c|}
\hline Age group Year & Frequency & Percentage \\
\hline Under 21 & 48 & 15 \\
\hline $21-30$ & 189 & 60 \\
\hline $31-40$ & 53 & 17 \\
\hline $41-50$ & 18 & 6 \\
\hline Above 50 & 7 & 2 \\
\hline Total & 315 & 100 \\
\hline
\end{tabular}

The table shows that sixty percent of participants are from age group of 21 to 30 and two percent of total participants are from the age group of above 50 years. It also shows that in the survey period, women in twenties are more active in buying products of cosmetics whereas the women of the age group of above fifty tend to buy less cosmetics items.

\section{Table 2}

Frequency Table of Income Group

\begin{tabular}{|c|c|c|}
\hline Income per month (in Rs.) & Frequency & Percentage \\
\hline Below 10000 & 69 & 22 \\
\hline $10000-20000$ & 120 & 38 \\
\hline $20001-30000$ & 47 & 15 \\
\hline $30001-40000$ & 38 & 12 \\
\hline 40001-50000 & 25 & 5 \\
\hline Above 50000 & 16 & $\mathbf{1 0 0}$ \\
\hline Total & $\mathbf{3 1 5}$ & 5 \\
\hline
\end{tabular}

For the purpose of survey income, groups are categorized into six groups; among them higher percent participants are from income level of ten thousand to twenty thousand 
whereas only five percent of respondents are from the income group of above fifty thousand per month. From this result we can conclude that women who have the income between ten thousand to twenty thousand are more active in buying cosmetic items in the same time, women who have more income has less participation in buying process of their cosmetic goods.

\section{Table 3}

Attitudes of Respondents for Packaging Design

\begin{tabular}{|c|c|c|}
\hline Influence factors & Frequency & Percentage \\
\hline Friend's Recommendation & 47 & 15 \\
\hline Packaging Design & 114 & 36 \\
\hline Price & 88 & 28 \\
\hline Brand & 66 & 21 \\
\hline Total & 315 & 100 \\
\hline
\end{tabular}

Table 3 presents respondents' purchasing attitude, which shows that higher percentage of the respondents are influenced by packaging design meanwhile fifteen percent women follow the suggestion and recommendations of their friend circle. From this result it is concluded that mouth to mouth advertisement also has the influence in cosmetic brands but with less proportion.

\section{Table 4}

Importance of Packaging Design

\begin{tabular}{|c|c|c|}
\hline Preference & Frequency & Percentage \\
\hline Important & 271 & 86 \\
\hline Not important & 44 & 14 \\
\hline Total & $\mathbf{3 1 5}$ & $\mathbf{1 0 0}$ \\
\hline
\end{tabular}

Table 4 indicates the responses toward importance of packaging design. The survey indicates that huge proportion of participants put argument towards importance of packaging design. So it had a significant impact on buying behavior of cosmetic products, although fewer respondents did not think packaging design as a significant factor. Thus this result also concludes that women in the Lalitpur city give more emphasis on packaging design when they buy the cosmetic products. 
Table 5

Influence by Packaging Style

\begin{tabular}{|c|c|c|}
\hline Style & Frequency & Percentage \\
\hline Classic \& Simple & 72 & 23 \\
\hline Cool Style & 60 & 19 \\
\hline Special Shape & 30 & 10 \\
\hline Lovely & 25 & 8 \\
\hline Retrospective and Old Style & 28 & 9 \\
\hline Fairy Tales & 28 & 13 \\
\hline Sexy \& Wild & 41 & 10 \\
\hline Sportive & 31 & 100 \\
\hline Total & 315 & 9 \\
\hline
\end{tabular}

Table 5 shows the influence of packaging style on buying behavior of the customers. The survey result revealed that twenty-three percent customers give more priority to classic and simple style packaging on the other hand only eight percent customer give priority to lovely style of packaging. From this result it is concluded that among Nepalese customer and culture classic and simple style of packaging is more popular than other although other style has the similar influence on buying behavior.

In the survey, it is also revealed that purpose of the buying also affects the selection of packaging design here, Attractive design packaging is selected to send their friends and family as a gift which response is fifty four percent, Similarly thirty nine percent respondent like to collect attractive design packaging product whereas seven percent respondents viewed buying such types of packaging cosmetics as wasting money.

\section{Results and Discussion}

The results show that packaging design generates positive product and brand evaluations. Packaging design, therefore, is an important predictor of the consumer evaluation of cosmetic products and brands. The result is consistent with Edward (2013). The packaging is viewed as an essential to fulfill the basic need of the consumers, and it should always be one step forward to consumer necessities and competitors. The study concludes that the customer's perceptions towards packaging products are highly influential to the strategies being adopted by the marketers in influencing and ensuring consumer buying behavior and pattern, through selected packaging strategies (Lavuri \& Porika, 2020), which is also similar result of this survey result. 
Packaging strategies have significant influence on buying intentions and behavior according to the study. Survey results revealed that customer give more priority to classic \& simple style packaging in Nepalese context. Furthermore, Mohammed, Medina, \& Romo, (2018) conclude that cosmetics consumer behavior was, in fact, affected by the visual elements of the cosmetics package designs and thus affected the consumers' purchase intentions similarly material and colors of the hairstyle, skin care, and makeup products packages were proved to be of high importance with respect to the level of attractiveness and affected consumers' preferences. So, conclusions of this survey result is also consistent with those finding.

Venter et al.,(2010) argues that participants' perceptions regarding packaging are shaped through an information processing system, with attention-capturing attributes of product packaging as the input or stimulus. This stimulus is communicated through packaging and represents the start of information processing in order to form a perception. Therefore, participants mainly perceived packaging based on its functional and physical attributes through unprompted awareness. This implies that packaging needs to serve a purpose, that it should guide the consumer in the proper use of the product and that it should adhere to certain visual criteria. In this way consumers have certain perceptions of food packaging and that they are aware of the potential influence of the packaging on the product. This is also the strong evidence behind this survey result.

\section{Conclusion}

The objective of this research was to determine the factors that can possibly affect consumer behavior at the point of sale. The results of this study showed that socio-demographic properties of consumers, price, product quality, package type, package attributes, labels and brands had higher influence on the purchasing decision of cosmetic product. In general, therefore, it seems that consumers in Lalitpur were not different from other countries' consumers with respect to buying behavior. It can be concluded that expectations of consumers are becoming more similar in the global world.

Moreover, if the cosmetic packaging does not encourage consumers' interest, they will not pay attention to it and they will therefore not respond to the product by choosing it. Hence, it is important for product packaging, including cosmetic packaging, to attract more attention than competitive products, in order to communicate the intended message regarding the product it contains to passing consumers. Consumers demand that cosmetic packaging should adhere to certain attributes before they will consider choosing it. If manufacturers can determine which product attributes are significant to consumers, then they will be able to create the importance of that product in consumers' minds by focusing product packaging appearance and design on these attributes. 
An aspect not covered during the current study, was whether participants would still purchase a cosmetic product if, according to their perceptions, the packaging does not suit the product. It is therefore recommended that this matter be investigated in further research. Future studies may also focus on types of packaging as well as other stimuli which give the shape of the perception.

\section{References}

Ampuero, O., \& Vila, N. (2006). Consumer perceptions of product packaging. The Journal of Consumer Marketing, 33 (2), 102-114.

Anselmsson, J., Johansson, U., \& Persson, N. (2007). Understanding price premium for grocery products: a conceptual model of customer-based brand equity. The Journal of Product and Brand Management, 16 (6), 401-414.

Atkin, T., Garcia, R., \& Lockshin, L. (2006). A multinational study of the diffusion of a discontinuous innovation. Australasian Marketing Journal, 14 (2), 17-33.

Behzad, M. (2014). An Art of packaging: an investigation into the role of color in packaging, marketing and branding. International Journal of Organizational Leadership, 3 (1), 92-102.

Clement, J. (2007). Visual influence on in-store buying decisions: an eye-track experiment on the visual influence of packaging design. Journal of Marketing Management, 23 (9), 917-928.

DeBono, K. G., Leavitt, A., \& Backus, J. (2003). Product packaging and product evaluation: an individual difference approach. Journal ofhology Applied Social Psy, 33 (3), 513-521.

Edward, S. W. (2013). The influence of visual packaging design on perceived food product quality, value, and brand preference. International Journal of Retail \& Distribution Management, 41 (10), 806-816.

Estire, M., Hasangholipour, T., Yazdani, H., Nejad, H. J., \& Rayej, H. (2010). Food Products Consumer Behaviors: The Role of Packaging Elements. Journal of Applied Sciences, 10 (7), 535-543.

Ghani, U., \& Kamal, Y. (2010). The impact of in-store stimuli on the impulse purchase behaviou of consummers in Pakistan. Interdisciplinary Journal of Contemporary Research in Business, 2 (8), 155-162.

Grunert, K. G. (2005). Food quality and safety: consumer perception and demand. European Review of Agricultural Economics, 32 (3), 369-391.

Hall, J., Binney, W., \& O'Mahony, G. B. (2004). Age related motivational segmentationof wine consumption in a hospitality setting. International Journal of Wine Marketing, 16 (3), 29-43.

Hellstrom, D., \& Nilsson, F. (2011). Logistics-driven packaging innovation: a case study at IKEA. International Journal of Retail \& Distribution Management, 39 (9), 638-657.

Honea, H., \& Horsky, S. (2012). The power of plain: intensifying product experience with neutral aesthetic context. Marketing Letters, 23 (1), 223-235.

Insch, A., \& Florek, M. (2009). Prevalence of country of origin associations on the supermarket shelf. International Journal of Retail \& Distribution, 37 (5), 453-471.

Johns, N., \& Pine, R. (2002). Consumer behaviour in the food service industry: A review. International Journal of Hospitality Management, 21 (2), 119-134. 
KabirChowdhury, M. H., \& Andaleeb, S. S. (2007). A Multivariate model of perceived quality in a developing country. Journal of International Consumer Marketing, 19 (4), 33-57.

Kauppinen-Raisanen, H., Owusu, R. A., \& Bylon, A. B. (2012). Brand salience of OTC pharmaceuticals through package appearance. International Journal of Pharmaceutical and Healthcare Marketing, 6 (3), 230-249.

Lavuri, R., \& Porika, R. (2020). Packaging strategies: knowledge outlook on consumer buying behaviour. Journal of Industry-University Collaboration, 2 (2), 67-78.

Linn, V. R., Eberhardt, T., Schutte, R., \& Kenning, P. (2012). Consumer trust in food retailers: Conceptual framework and empirical evidence. International Journal of Retail \& Distribution Management, 40 (4), 254-272.

Mohammed, N. B., Medina, I. G., \& Romo, Z. G. (2018). The effect of cosmetics packaging design on consumers' purchase decisions. Indian Journal of Marketing, 48 (12), 50-61.

Mueller, S., Lockshin, L., \& Jordan, J. L. (2010). What you see may not be what you get: asking consumers what matters may not reflect what they choose. Marketing Letters, 21 (4), 335-350.

Noad, J., \& Rogers, B. (2008). The importance of retail atmospherics in B2B retailing: the case of BOC. International Journal of Retail \& Distribution Management, 36 (12), 1002-1014.

Sehrawet, M., \& Kundu, S. C. (2007). Buying behaviour of rural and urban consumers in India: the impact of packaging. International Journal of Consumer Studies, 31 (6), 630-638.

Silayoi, P., \& Speece, M. (2007). The importance of packaging attributes: a conjoint analysis approach. European Journal of Marketing, 41 (11/12), 1495-1517.

Silayoi, P., \& Speece, M. (2007). The importance of packaging attributes: a conjoint analysis approach. European Journal of Marketing, 41 (11/12), 1495-1517.

Thalhammer, R. (2007). Natural product packaging: reflecting a contemporary philosophy. Global Cosmetic Industry, 175 (12), 52-55.

Venter, K., Merwe, D. v., Beer, H. d., Kempen, E., \& Bosman, M. (2010). Consumers' perceptions of food packaging: an exploratory investigation in Potchefstroom, South Africa. International Journal of Consumer Studies, 35 (3), 273-281.

Venter, K., Van der Merwe, D., de Beer, H., Kempen, E., \& Bosman, M. (2011). Consumers perceptions of food packaging: an exploratory investigationin Potchefstroom, South Africa. International Journal of Consumer Studies, 35 (3), 273-281.

Wang, Y., \& Heitmeyer, J. (2006). Consumer attitude toward US versus domestic apparel in Taiwan. International Journal of Consumer Studies, 30 (1), 64-74.

Wigley, S., \& Chiang, C. L. (2009). Retail internationalisation in practice: Per una in the UK and Taiwan. International Journal of Retail \& Distribution Management, 37 (3), 250-270. 